Arab World English Journal (AWEJ) Volume 12. Number2 June 2021

DOI: https://dx.doi.org/10.24093/awej/vol12no2.14

Pp.209-221

\title{
A Task-based Teaching Approach with Multiple Intelligences Features in Developing Chinese Students' Speaking Competency
}

\author{
JIAJUN XU \\ College Department, Heilongjiang International University \\ Harbin, China
}

Received: $1 / 25 / 2021$

Accepted: 4/6/2021

Published:6/24/2021

\section{Abstract}

The study aimed to achieve three objectives: 1) to identify the Multiple Intelligences (MI) perceived by Heilongjiang International University (HIU) students, 2) to develop and implement a task-based English speaking course with MI features, and 3) to evaluate the extent the developed English speaking course contributes to the improvement of HIU students' speaking abilities based on complexity, accuracy, and fluency (CAF) components. The study was carried out with 30 experimental and 30 control group students at Heilongjiang International University, China. Data were collected by a questionnaire survey, the pre-test and post-test, and the final tests focusing on complexity, accuracy, and fluency components. The data were analyzed using the primary statistical measurements by identifying the Mean (M) and the Standard Deviation (SD), and the significance level. The results indicated that with regard to HIU students' selfperceived MI, Music Intelligence was perceived higher, while the Logical-mathematical Intelligence was perceived lower. As for the students' speaking ability, the results indicated that there was improvement found between the pre-test and the post-test in the COMPLEXITY with the significance value of .001, the ACCURACY significance value was .002, and the FLUENCY significance value was .001 . The conclusion is that the task-based teaching practices with MI features contribute to the improvement of students' speaking abilities in terms of complexity, accuracy and fluency. The findings are followed by some implications for teaching and learning. Keywords: accuracy, complexity, fluency, Heilongjiang International University, multiple intelligence, task-based language teaching

Cite as: XU, J. (2021). A Task-based Teaching Approach with Multiple Intelligences Features in Developing Chinese Students' Speaking Competency. Arab World English Journal, 12 (2)

209-221. DOI: https://dx.doi.org/10.24093/awej/vol12no2.14 


\section{Introduction}

In many educational contexts, the assessment of the second language (L2) speaking performances relies on rating scales to award scores to language learners' achievement. One scaling is the analytic rating scale which is widely used in L2 performance assessments. Such rating is created through experts' intuitive judgment or adaptation of existing rating scales from one assessment context to another. According to Bond and Fox (2015), it is essential to investigate the efficacy of rating scales empirically to make sure that the data is of high quality.

The central dimensions of L2 speaking proficiency are believed to be productively measured by the notions of these different components, complexity, accuracy, and fluency, referred to as CAF by Housen, Kuiken, and Vedder (2012). Complexity refers to the elaborateness and variety of grammar and vocabulary used by students, accuracy is about the degree of correctness or deviance from the norm used by learners, and fluency is about the ease or smoothness of speech (Yan, Kim \& Kim, 2018) in which its' multilayered construct can be both theoretical and practical to measure the improvement better. Speaking is one of the most essential skills to be acquired for learning English as a foreign language, as it is viewed as a collaborative and interactive process (Cole et al. 2007). Through speaking or oral communication, people can agree or disagree, interrupt with or expand what was said. Good communication can eliminate obstacles that hinder understanding. Accordingly, a good speaking ability cultivates learners' confidence to interact with others and is viewed as one indicator of a learner's language proficiency. So, providing learners with tasks that illustrate such abilities through the use of the Task-Based Learning (TBL) approach helps assess how students create meaning by using their linguistic resources. Ellis (2003) believed that TBL is good in teaching and learning a language. This is regarded as an open-ended task and revealed that TBL follows a learner-centered educational philosophy as it is content-oriented. Willis (1996), Prabhu (1987), and Nunan (1989) argued that the task-based learning framework contains three main stages for language learning, the pre-task, task-cycle (task), and post-task stages (language focus), and also indicated that these phrases are planned carefully to produce the most satisfactory language acquisition conditions and thus offer valuable learning opportunities to match different types of learners.

The notion of general intelligence proposed by Gardner (1993) is that each learner has independent intelligence or a mixture of several abilities or Multiple Intelligences (MI), which could not be measured on a single scale. As this study deals with identifying university students' intelligences, the most reasonable step to be taken is to let university students identify their 'perceived intelligences' by conducting a survey where they need to identify their intelligences. The researcher believes that students have known their intelligences better than those who observe them $(\mathrm{Xu}, 2020)$, which is why letting them assess their own 'intelligences' was the first ground of this research.

The study focused on the development of task-based learning integrated with the features of MI perceived by Heilongjiang International University (HIU) students for the English speaking course using three components: complexity, accuracy, and fluency (CAF). The researcher employed various discourse analytical measures and quantified CAF subcomponents that influenced HIU students' differing levels of proficiency. 
There are three objectives as guidelines:

1. To identify male and female HIU students' self-perceived Multiple Intelligence (MI).

2. To develop and implement the development of a task-based English speaking course with MI features and

3. To evaluate the improvement of the experimental group students' speaking abilities based on complexity, accuracy, and fluency components.

\section{Literature Review}

\section{Assessment of English Speaking}

For many years, attention has been focusing on speaking skills and their significance in foreign language learning. Brown (1991) revealed that serious consideration of spoken language as a subject for teaching has a long history. Egan (1999) also considered speaking as the core of second language learning. However, this particular skill seems to be neglected concerning teaching and assessment, specifically in the context of China. According to Gammidge (2004), though speaking is essential for foreign language learners, learning this skill tends to be difficult. To speak confidently, a learner needs to build his/her language resources even in the essential interaction. Nitta and Nakatsuhara (2014) have proposed adding measures of interactional competence, such as the length of turn to their discourse analytic measures, to better represent the co-constructed nature of dialogic speech by paying attention to dialogic speaking tasks. Ockey and Li (2015) argued that an individual's underlying ability could be actively structured in response to incoming stimuli, such as the information given by other speakers. Some researchers like Tong-Fredericks (1984) used a wide range of specific measures to quantify learner production. For example, they measured the number of words learners produced per minute of speaking, the frequency of turns, and the amount of self-correcting was also assessed. Also, Berwick (1990) measured the interaction by examining several variables related to language production, for example, the exophoric references and the use of context-bound referential pronouns such as "this" and "these", and anaphoric reference, such as the use of pronouns to refer back to previously mentioned referent. Brown (1991) measured the task performance in terms of repetitions, prompts, rephrasing, repairs, and instructional input, when speakers explained something to another.

Newton and Kennedy (1996) investigated task-based production in terms of specific linguistic features, prepositions, and conjunctions in which measures have been intuitively chosen as data-driven rather than theory-based. Skehan's research (1996) focused on the distinction between complexity, accuracy, and fluency and had drawn on his theoretical claims about a dual competence system and trade-offs in learners' focus of attention. As this involved a degree of interpretation, Skehan and Foster (1997) reported that the measure of fluency, accuracy, and complexity obtained from learners' performance of three different tasks was under predictions, which suggests that these dimensions of performance are indeed distinct and can be measured separately.

To date, although various measures have been available to assess the CAF triad (Ellis, 2005, 2008, 2009), Second Language Acquisition researchers have recommended to know and provide details on what facets of complexity, accuracy, and fluency they intend to measure (Norris \& Ortega, 2009). Thus, using multiple measures for assessing each dimension of 
performance (CAF) may yield a more valid and comprehensive picture of a construct if different facets could be measured.

\section{Multiple Intelligences and English Language Teaching and Learning}

Many scholars believe that MI can be integrated into English language teaching and learning (Gardner, 2011; Jones, 2017; Luo, 2018; Shearer, 2020). They perceive that this can be a building block for English acquisition, enhancement of all intelligences, and serves as an alternative for providing different assessments to help students further improve their academic achievements (Gardner, 2011; Luo, 2018). According to them, acknowledging multiple intelligences and using them as a tool to organize teaching and learning methods could help to avoid the 'one size fits all' teachers' mentality to develop students' learning abilities (Jones, 2017; Spirovska, 2013). Robinson and Aronica (2014) indicated that integrating different intelligences such as linguistic intelligence, musical intelligence, logical-mathematical intelligence, visual-spatial intelligence, bodily-kinesthetic intelligence is beneficial to students simply because each intelligence has its strength. Spirovska (2013) argued that MI has different benefits in the English language classroom. However, teachers should adopt a student-centered approach to teaching and learning and employ a dynamic and non-conventional teaching method so that students would bring out the best of their capacities and abilities (Zhang, 2017).

Collaborative learning focuses on a student-centered approach, and sharing ideas and expertise is part of the strengths of MI in the English language classroom. Teachers need to play their roles in the students learning process. When implementing the MI approach to teaching, teachers need not only focus on the failure of their students but strengths and abilities so that students will be motivated to engage more in the class (Shearer, 2020).

In this study, the task-based language teaching approach model was paired with HIU students' self-reported preferred Multiple Intelligences to create an English speaking course. The aim is to improve students' English speaking abilities and assess the effectiveness of the course by measuring the improvement of the students concerning three components, fluency, accuracy, and complexity.

This study aims to answer this research question: To what extent, the Chinese students speaking ability with regard to fluency, accuracy, and complexity (CAF) can be developed with the help of a task-based teaching and learning approach with multiple intelligences features?

\section{Methods}

The present is a quantitative study using primary statistical tools. 359 students at Heilongjiang International University, China, completed the 35-item questionnaire about MI preferences to answer the first research objective. To answer the second research objective, a task-based English speaking course with MI features was developed implemented among 30 experimental group students. And to answer the third research objective, the pre-test and posttest results will be used to identify the 30 experimental group students' speaking ability improvement, and further, the post-test results of the experimental group students will be compared with another 30 control group students' final test results.

\section{Instrumentation}


The survey questionnaire was the 35-item MI questionnaire which was divided into seven parts. Each part includes five questions representing one self-perceived MI dimension. The 5Likert scaling was employed to calculate the result of the findings, ranging from $1-5$, in which $1=$ indicated a strongly disagreement and $5=$ strongly agreement.

\section{Validity and Reliability}

To get the validity and reliability of the instruments, first, the questionnaire was measured using Cronbach's Alpha. The measurement was .917, which indicated that the reliability of the questionnaire was achieved. Furthermore, the construct validity of the items and underlying variables of seven MI dimensions was measured. The CFI (Comparative Fit Index) value was .765. The NFI (Normed Fit Index) was .677, and IFI (Incremental Fit Index) was .768, which indicated that the construct validity of the questionnaire was also achieved.

The reliability of all the variables based on complexity, accuracy, and fluency of the instruments was tested. The Cronbach's Alpha is .773, which is considered acceptable, so the reliability of the CAF instruments was achieved. The construct validity of the CAF instruments was also tested, and GFI (Goodness of Fit Index) is .950, NFI is .743, IFI (Incremental Fit Index) is .986, and CFI (Comparative Fit Index) is .982, which is all above .70, and indicates that the construct validity of the CAF instruments was also achieved.

\section{The Research Process}

The research process was composed of three phases:

The first phase was started by the distribution of the questionnaire survey, which would help to identify HIU students' self-perceived Multiple Intelligences, and the MI differences between male and female students were also addressed.

The second phase was the development of the English speaking course where features of MI perceived by the students were integrated into the English speaking materials and activities used, using the Task-based learning approach, which was followed by the implementation of the developed speaking course. The goal was to improve HIU students' English speaking abilities in terms of complexity, accuracy, and fluency.

The teaching of the lesson plans, the topics, and activities based on the task-based teaching framework was constructed to achieve the second objective. Appendix A presented the topics and objectives of each topic. Appendix B presented the topic and the content of the teaching materials. And Appendix $\mathrm{C}$ presented the variables of the three components, complexity, accuracy, and fluency used for assessing the speaking materials (Ellis, 2003).

In the third phase, the values of each variable under Fluency, Accuracy, and Complexity were collected and calculated. The pre-test speaking scores and post-test speaking scores from the experimental group of students were analyzed using the data analysis software in terms of paired T-test. The scores of the final speaking test based on complexity, accuracy, and fluency from the control group were analyzed and compared with the post-test scores of the experimental group using the data analysis software in terms of independent T-test. The aim was to compare the mean value to observe the changes between the experimental and control group of students with regard to the speaking scores. 


\section{Findings and Discussions}

The findings of Objective 1:

To find out HIU students' self-perceived Multiple Intelligences, descriptive statistics were used by finding the mean value and standard deviation, which was followed by identifying the differences between male and female students. The results were presented in the following table:

Table 1. Descriptive statistics of the mean value of Multiple Intelligences (MI)

\begin{tabular}{lclc}
\hline \multicolumn{1}{c}{ MI Type } & No. of Students & Mean Score & Standard Deviation \\
\hline Linguistic & 359 & 14.45 & 3.140 \\
\hline Logical-mathematical & 359 & 13.46 & 3.190 \\
\hline Music & 359 & 15.66 & 3.909 \\
\hline Bodily-kinesthetic & 359 & 13.62 & 3.587 \\
\hline Visual-Spatial & 359 & 14.00 & 3.042 \\
\hline Interpersonal & 359 & 14.57 & 3.250 \\
\hline Intrapersonal & 359 & 14.39 & 3.077 \\
\hline
\end{tabular}

Table One shows that the Mean (M) and Standard Deviation (SD) scores of MI varied from $\mathrm{M}=13.46$ with the $\mathrm{SD}=3.19$ to $\mathrm{M}=15.66$ and $\mathrm{SD}=3.909$. The Musical Intelligence has the highest Mean (M) $=15.66$ and $\mathrm{SD}=3.909$. This was followed by the interpersonal, linguistic, intrapersonal, visual-spatial, bodily-kinesthetic, and the logical-mathematical respectively. The scores of Multiple Intelligence (MI) indicated that students' perceived themselves as MIdominated. As Chinese learners tend to be influenced by Grammar Translation or Audio-lingual in China context, perhaps, utilizing this intelligence to develop their vocabulary acquisition through music can be their strengths. According to Gardner, music can be used in an educational context to develop and express students' ideas through exploration and exploitation of the oralaural channel (Gardner, 2011, p.129).

To identify HIU male and female students' self-perceived MI differences, 80 males and 80 female students were chosen from the data and tested.

Table 2. Perceived-Multiple Intelligences of HIU male and female students

\begin{tabular}{lllll}
\hline \multirow{2}{*}{ MI Types } & Gender & Number & Mean & SD \\
\hline \multirow{2}{*}{ Linguistic } & male & 80 & 14.91 & 3.691 \\
\cline { 2 - 5 } & female & 80 & 14.31 & 3.000 \\
\hline \multirow{2}{*}{ Logical* } & male & 80 & 14.60 & 3.814 \\
\cline { 2 - 5 } & female & 80 & 12.86 & 2.755 \\
\hline \multirow{2}{*}{ Musical } & male & 80 & 16.70 & 4.268 \\
\cline { 2 - 5 } & female & 80 & 15.75 & 3.866 \\
\hline \multirow{2}{*}{ Bodily-kinesthetic* } & male & 80 & 15.10 & 4.289 \\
\cline { 2 - 5 } & female & 80 & 12.93 & 2.814 \\
\hline \multirow{2}{*}{ Visual-spatial } & male & 80 & 14.41 & 3.679 \\
\cline { 2 - 5 } Interpersonal* & female & 80 & 13.86 & 2.727 \\
\hline Intrapersonal & male & 80 & 15.64 & 4.098 \\
\cline { 2 - 5 } & female & 80 & 13.94 & 3.739 \\
\hline
\end{tabular}




\begin{tabular}{cccc}
\hline female & 80 & 14.24 & 2.466 \\
\hline$*$ Significant Difference at the 0.01 level (2-tailed) & &
\end{tabular}

Table Two illustrates that male students' self-perceived MI is higher than females among the seven intelligences. Male students indicated that their highest self-perceived MI is Musical Intelligence, and their lowest self-perceived intelligence is Visual-spatial Intelligence with the lowest self-perceived MI of $\mathrm{M}=14.41$ and $\mathrm{SD}=3.679$. Similarly, female students' highest selfperceived MI was Musical intelligences with $\mathrm{M}=15.75$ and $\mathrm{SD}=3.866$ while the lowest selfperceived $\mathrm{MI}$ is Logical Intelligence with $\mathrm{M}=12.86$ and $\mathrm{SD}=2.755$.

Interestingly, it was indicated that there were significant differences between male and female MI in terms of the three intelligences, Logical Intelligence, Bodily-kinesthetic Intelligence, and Interpersonal Intelligence where the male students always show HIGHER than female students. According to Gardner (2011), people who are high in logical-mathematical are perceived to be good with abstract entities of numbers. Also, these individuals tend to question and answer their limits by exploring, analyzing, categorizing, and working in different ways (Gardner, 2011). Nonetheless, people who are high in bodily-kinesthetic intelligence tend to use non-verbal communication or body language often to communicate, whereas, interpersonal intelligence involves the moods in communication or how a person interacts with others. While people who are HIGH in interpersonal intelligence tend to have a good relationship with others as they can express and discuss their ideas with others clearly (Gardner, 2011).

Table 3. Comparison between post-test and pre-test

\begin{tabular}{lllllll}
\hline & & Mean & SD & t & df & Sig (2-tailed) \\
\hline 1 & Complexity2-Complexity1 & 3.800 & 5.768 & 3.608 & 29 & .001 \\
2 & Accuracy2-Accuracy1 & 4.066 & 6.542 & 3.404 & 29 & .002 \\
3 & Fluency2-Fluency1 & 7.767 & 11.545 & 3.685 & 29 & .001 \\
& & & & & & \\
\hline
\end{tabular}

In the comparison between each pair using Paired T-test, the complexity shows a .001 significance value, the mean value is equivalent to $\mathrm{M}=3.800$ with the $\mathrm{SD}=5.768$, the accuracy pair shows the mean is equivalent to $\mathrm{M}=4.066$, with $\mathrm{SD}=6.542$ and the significance value is .002 , the fluency pair shows the mean is $\mathrm{M}=7.767$, with $\mathrm{SD}=11.545$ and the significance value is .001 . Based on the results, it indicated that there was an improvement statistically in complexity, accuracy, and fluency among HIU students.

Table 4. Comparison between the experimental and the control group of HIU students

\begin{tabular}{llllll}
\hline & & Mean & SD & t & Sig (2-tailed) \\
\hline 1 & Complexity2-Complexity3 & 3.033 & 1.326 & 2.288 & .026 \\
2 & Accuracy2-Accuracy3 & 6.411 & 1.814 & 3.534 & .001 \\
3 & Fluency2-Fluency3 & 7.433 & 3.491 & 2.129 & .038 \\
\hline
\end{tabular}

Table Four indicates that the comparison between each pair using Independent Sample T-test based on the Mean and the Standard Deviation (SD), the complexity pair indicated the Mean value, $M=3.033$ with the $S D=1.326$, with the significance value .026 ; the accuracy pair, the $\mathrm{M}=6.411$ and the $\mathrm{SD}=1.814$, with the significance value .001 ; the fluency pair, the $\mathrm{M}=7.433$ and the $\mathrm{SD}=3.491$, with the significance value .038 , therefore, with regard to the comparison between 
the experimental and the control group in terms of complexity, accuracy, and fluency, there was also an improvement.

\section{Pedagogical Implications}

A few pedagogical implications on teaching and learning based on the experimental study in which the task-based approach with Multiple Intelligences features was developed are:

First, when designing a course, using the task-based teaching framework, necessary steps should be planned appropriately. This should start with the objectives and goals to meet the needs of students. When deciding the topics used in speaking, the teaching materials, topics, and activities should always support students' ability levels, learning styles, and needs. As learning can be a slow process, especially for the learners who learned English as a foreign language, the results cannot be achieved for a short period of time.

Second, as this experimental English-speaking course was taught online, therefore some approaches need to be considered whether this can be used in this particular mode of teaching. Therefore, further experimentation needs to be done to see to it what type of learning environment a task-based approach to teaching and learning works best, especially if it is combined with MI features. Accordingly, as a task-based teaching approach is best taught in a student-centered environment, online teaching therefore might be worth trying to adapt to the pandemic environment. However, a classroom can still be viewed as suitable learning environments as real interaction and communication are needed to see the effectiveness of the lessons. Therefore, depending on the approach a teacher used, the efficiency of the lesson relies on teaching activities, teaching styles, and the mode of learning.

Third, although Multiple Intelligences (MI) approach has been used by different educators for many years, teachers should take into account what intelligences best suit each student. Therefore, teachers and learners' fundamental beliefs about teaching and learning need more reflection, and the task-based approach model with MI dimensions can be used effectively to enhance students' speaking abilities. TBL is an open-ended task, and more activities should be used to support this approach, as one of its strengths is student-centered types of teaching and learning.

\section{Conclusion}

This study was divided into three phases: Phase One was about identifying HIU students' perceived intelligences. Phase Two was the course design using the Task-based approach teaching and learning based on HIU students' perceived intelligences and the course implementation of the teaching materials and activities. Phase Three was the assessment of its effectiveness in three components: complexity, accuracy, and fluency.

With the quantitative method for the analysis, the results indicated significant improvement after the experiment with regard to complexity, accuracy and fluency. This result was consistent as the experimental and control group results based on the three components of speaking, complexity, accuracy, and fluency, have a statistical significance at the level of .05. 
The concluding statement, therefore, is that the development of the task-based English speaking course with MI features did improve HIU students' complexity, accuracy, and fluency in English speaking.

\section{About the author:}

Jiajun $\mathrm{Xu}$ is an English teacher at Heilongjiang International University, China. He is interested in English language teaching and teacher training, and is now doing PhD ELT at Assumption University, Thailand from 2018. https://orcid.org/0000-0003-3902-7836

\section{References}

Berwick, R. (1990). Task variation and repair in English as a foreign language. Institute of Economic Research. Kobe University of Commerce.

Bond, T. G., \& Fox, C. M. (2015). Applying the Rasch model: Fundamental measurement in the human sciences. (3rd ed.). New York: Routledge.

Brown, R. 1991. Group work, task difference, and second language acquisition. Applied Linguistics. 21, pp. 1-12. Cambridge: Cambridge University Press.

Cole, D. et al. (2007). Teaching speaking and listening: a toolkit for practitioners. Bristol: Portishead press.

Egan, K. B. (1999). Speaking: A critical skill and a challenge. Calico Journal, 16 (3): 277.

Ellis, R., \& Barkhuizen, G. (2003). Analyzing learner language. Oxford: Oxford University Press.

Ellis, R. (2005). Planning and task performance in a second language.Amsterdam: John Benjamins.

Ellis, R. (2008). The study of second language acquisition. 2nd edition. Oxford: Oxford University Press.

Ellis, R. (2009). The differential effects of three types of task planning on the fluency, complexity, and accuracy in L2 oral production. Applied Linguistics, 30, (4) 474509.

Gammidge, M. (2004). Speaking Extra: A resource book of multi-level skills activities. Cambridge: Cambridge University Press.

Gardner, H. (1993). Frames of mind: The theory of multiple intelligences. New York, NY: Basic Books.

Gardner, H. (2011). Frames of Mind: The Theory of Multiple Intelligences. (2nd ed). New York: Basic Books.

Housen, A., Kuiken, F., \& Vedder, I. (2012). Complexity, accuracy, and fluency: Definitions, measurement, and research. In A. Housen, F. Kuiken, \& I. Vedder (Eds.). Dimensions of L2 performance and proficiency: Complexity, accuracy, and fluency in SLA (pp.1-20). Amsterdam: Benjamins. https://doi.org/10.1075/1llt.32.01hou.

Jones, E. (2017). One size fits all? Multiple intelligences and legal education. The Law Teacher, 51(1), 56-68.

Luo, S. (2018). Multiple Intelligences. The TESOL Encyclopedia of English Language Teaching, $1-8$.

Newton, J. \& Kennedy, G. (1996). Effects of communication tasks on the grammatical relations marked by second language learners. System 24 (3): 309-22. 
Nitta, R., \& Nakatsuhara, F. (2014). A multifaceted approach to investigating pre-task planning effects on paired oral task performance. Language Testing, 31 (2), 147-175. https://doi.org/10.1177/0265532213514401.

Norris, J.M. \& Ortega, L. (2009). Towards an organic approach to investigating CAF in instructed SLA: The case of complexity. Applied Linguistics, 30 (4), 555-78.

Nunan, D. (1989). Designing tasks for the communicative classroom. Cambridge: Cambridge University Press.

Ockey, G. J., \& Li, Z. (2015). New and not so new methods for assessing oral communication. Language Value, 7(1), 1-21

https://doi.org/10.6035/LanguageV.2015.7.2.

Prabhu, N.S. (1987). Second language pedagogy. Oxford: Oxford University Press.

Robinson, K., \& Aronica, L. (2014). Finding your element: How to discover your talents and passions and transform your life. London: Penguin Books.

Shearer, C. B. (2020). Multiple intelligences in gifted and talented education: Lessons learned from neuroscience after 35 years. Roeper Review, 42(1), 49-63.

Skehan, P., \& Foster, P. (1997). Task type and task processing conditions as influences on foreign language performance. Language Teaching Research 1: 185-211.

Skehan, P. (1996) A framework for the implementation of task-based instruction. Applied Linguistics, 17(1), 38-62.

Spirovska, E. (2013). Integrating Multiple Intelligences in Teaching English as a Foreign Language- SEEU Experiences and Practices. SEEU Review: Versita, 9 (1), 1-12. DOI: $10.2478 /$ seeur-2013-0002

Tong-Fredericks, C. (1984). Types of oral communication activities and the language they generate a comparison. System 12(2): 133-4.

Willis, J. (1996). A framework for Task-based learning. London: Longman.

$\mathrm{Xu}$, J. (2020). Identifying Students' Self-perceived Multiple Intelligence Preferences: the Case of Students from Heilongjiang International University, China. Arab World English Journal, 11 (2) 59-69. DOI:

https://dx.doi.org/10.24093/awej/vol11no2.5.

Yan, X, Kim, H.R., \& Kim (2018). Complexity, Accuracy and Fluency (CAF) Features of Speaking Performances on Aptis Across Different Levels on the Common European. Retrieved from https://www.britishcouncil.org/complexity-accuracyand-fluency-caf-features-speaking-performances-aptis-across-different-

levels\#: :text=An\%20array\%20of\%20CAF\%20features,accuracy \%2C\%20fluency $\% 2 \mathrm{C} \% 20$ and \%20pronunciation

Zhang, F. (2017). Research on the cultivation of Chinese competitive sports reserve talents based on the theory of Multiple Intelligences. Proceedings of the 3rd Conference on Education and Teaching in Colleges and Universities (CETCU 2017) (pp. 167170). Atlantis Press.

Appendix A: Topics and its objectives

\begin{tabular}{ll}
\hline Topic & \multicolumn{2}{c}{ Objective } \\
\hline Getting to & $\begin{array}{l}\text { Mastering the spoken language and skills in expressing his or her } \\
\text { know }\end{array}$ \\
& $\begin{array}{l}\text { Sharing and presenting their understanding of their personality (pros and } \\
\text { cons). }\end{array}$
\end{tabular}




\begin{tabular}{|c|c|}
\hline $\begin{array}{l}\text { Food } \\
\text { Cooking }\end{array}$ & $\begin{array}{l}\text { Mastering the spoken language and skills in ordering food in four kinds of } \\
\text { restaurants; } \\
\text { Sharing and presenting how to cook their favorite food through real-life } \\
\text { videos. }\end{array}$ \\
\hline $\begin{array}{l}\text { Climate } \\
\text { Weather }\end{array}$ & $\begin{array}{l}\text { Mastering the spoken language and skills in expressing and talking about } \\
\text { the weather in different seasons; } \\
\text { Sharing and presenting their solutions about extreme weather through real } \\
\text { life videos to know that climate changes, culture changes, and we have to } \\
\text { adjust to nature. }\end{array}$ \\
\hline Jobs & $\begin{array}{l}\text { Mastering the spoken language and skills in job hunting; } \\
\text { Sharing and presenting what they would do to get their dream jobs by } \\
\text { watching the video about HR's secrets of job recruitment; } \\
\text { Thinking about what success means by watching Arnold's speech about the } \\
\text { rules of success. }\end{array}$ \\
\hline $\begin{array}{l}\text { Hobbies and } \\
\text { Interests }\end{array}$ & $\begin{array}{l}\text { Mastering the spoken language and skills in expressing hobbies and } \\
\text { interests; } \\
\text { Knowing the differences among hobbies, jobs, careers, and vocations by } \\
\text { watching videos; } \\
\text { Sharing and presenting what their hobbies are and what they will do to } \\
\text { balance their future jobs and hobbies. }\end{array}$ \\
\hline $\begin{array}{l}\text { Transportation } \\
\text { and Travel }\end{array}$ & $\begin{array}{l}\text { Mastering the spoken language and skills in distinguishing road signs when } \\
\text { driving and in airport English about world traveling; } \\
\text { Sharing and presenting what life they choose to live when retiring and why } \\
\text { by watching introductions of places around the world. }\end{array}$ \\
\hline $\begin{array}{l}\text { Animals and } \\
\text { Nature }\end{array}$ & $\begin{array}{l}\text { Mastering the spoken language and skills in distinguishing and naming } \\
\text { animals; } \\
\text { Sharing and presenting what they think about the relationship between } \\
\text { humans, animals, and nature by watching a video named " } 10 \text { Incredible } \\
\text { Relationships Between Animals and Human". }\end{array}$ \\
\hline Sports & $\begin{array}{l}\text { Mastering the spoken language and skills in expressing sports they like; } \\
\text { Sharing and presenting what they think about the spirit of sports; } \\
\text { Knowing the spirit of sports in a new way: respect and perseverance }\end{array}$ \\
\hline
\end{tabular}

Appendix B : Topics and contents of teaching materials

\begin{tabular}{|c|c|c|}
\hline Topic & & \\
\hline $\begin{array}{l}\text { Getting } \\
\text { Know }\end{array}$ & to & $\begin{array}{l}\text { 100+ Adjectives to Describe Personality and Character(video with } \\
\text { subtitles); } \\
\text { Self-introduction(video with subtitles); } \\
\text { Being an Introvert is a Good Thing(video with subtitles); } \\
\text { Who Is the Right Person for You (Personality Test)(video with subtitles). }\end{array}$ \\
\hline $\begin{array}{l}\text { Food } \\
\text { Cooking }\end{array}$ & & $\begin{array}{l}\text { Ways of Cooking Vocabulary with Picture, Pronunciation, and Definition } \\
\text { (video with subtitles and pictures); } \\
\text { Ordering food in English (video with subtitles); } \\
\text { How to cook the best restaurant-style fried rice (video with subtitles). }\end{array}$ \\
\hline Climate & & How to talk about WEATHER in English - grammar, adjectives, verbs, \\
\hline
\end{tabular}




\begin{tabular}{|c|c|}
\hline Weather & $\begin{array}{l}\text { nouns \& idioms (video with subtitles); } \\
\text { What Causes Day Length to Change from Summer to Winter(video with } \\
\text { subtitles); } \\
\text { Extreme weather needs extreme solutions (video with subtitles). }\end{array}$ \\
\hline Jobs & $\begin{array}{l}\text { List of Jobs and Occupations- Learn Different Types of Jobs with } \\
\text { Pictures(video with subtitles); } \\
\text { List of Professions- Useful Jobs Vocabulary and Job Names in English } \\
\text { with Pictures(video with subtitles); } \\
7 \text { Secrets to Hiring Great People(video with subtitles); } \\
\text { Arnold Schwarzenegger This Speech Broke The Internet AND Most } \\
\text { Inspiring Speech- It Changed My Life(video with subtitles); } \\
\text { STOP wasting your life (video with subtitles). }\end{array}$ \\
\hline $\begin{array}{l}\text { Hobbies and } \\
\text { Interests }\end{array}$ & $\begin{array}{l}\text { Hobbies and interests- English Language(video with subtitles); } \\
\text { Hobbies, Jobs, Careers, \& Vocation(video with subtitles); } \\
\text { Students' hobbies and interests (video with subtitles). }\end{array}$ \\
\hline $\begin{array}{l}\text { Transportation } \\
\text { and Travel }\end{array}$ & $\begin{array}{l}\text { Transportation Vocabulary(video with subtitles); } \\
\text { Useful Phrasal Verbs for TRAVEL in English(video with subtitles); } \\
\text { Airport Vocabulary - English for Travel(video with subtitles); } \\
\text { Step by Step Guide for Airport English(video with subtitles); } \\
\text { The } 10 \text { Countries to Live or Retire (video with subtitles). }\end{array}$ \\
\hline $\begin{array}{l}\text { Animals and } \\
\text { Nature }\end{array}$ & $\begin{array}{l}\text { List of Animals! Learn 100+ Animals with Pictures(video with subtitles); } \\
10 \text { Incredible Relationships Between Animals And Human(video with } \\
\text { subtitles); } \\
\text { Dear Future Generations- Sorry(video with subtitles). }\end{array}$ \\
\hline Sports & $\begin{array}{l}\text { List of Sports- Types of Sports and Games in English (video with } \\
\text { subtitles); } \\
20 \text { BEAUTIFUL MOMENTS OF RESPECT IN SPORTS(video with } \\
\text { subtitles); } \\
\text { I Did Murph Workout for } 30 \text { Days; Here's How My Body Changed (video } \\
\text { with subtitles). }\end{array}$ \\
\hline
\end{tabular}

Appendix C: The variables for the assessment of the outcome

Complexity Number of turns per minute (NTPM)

Lexical richness (percentage of lexical to structural words) (LR)

Percentage of words functioning as lexical verbs (FLV)

Amount of subordination (total number of clauses divided by the total number of c-units) (AS)

Frequency of use of conjunctions (FUC)

Frequency of use of prepositions (FUP)

Accuracy Number of self-corrections (NSC) 
Arab World English Journal (AWEJ) Volume 12. Number 2. June 2021

Percentage of error-free clauses (PEFC)

Target-like use of verb tenses (VT)

Target-like use of articles (A)

Target-like use of plurals $(\mathrm{P})$

The ratio of indefinite to definite articles (RIDA)

Fluency Number of words per minute (NWPM)

Number of syllables per minute (NSPM)

Number of pauses ( over one second) (NP)

Mean length of pauses (in second) (MLP)

Number of repetitions (NRP)

Number of reformulations (NRF)

Mean length of the run (MLR)

Number of words per run (NWPR) 